\title{
Using UHPLC-MS Profiling for the Discovery of New Dihydro- $\beta$-Agarofurans from Australian Celastraceae Plant Extracts
}

\author{
Mario Wibowo ${ }^{1}$, , Paul I. Forster ${ }^{2}$, Gordon P. Guymer ${ }^{2}$, Andreas Hofmann ${ }^{1,3}$ and \\ Rohan A. Davis $1, * \mathbb{D}$ \\ 1 Griffith Institute for Drug Discovery, Griffith University, Brisbane, QLD 4111, Australia; \\ mario.wibowo@griffithuni.edu.au (M.W.); a.hofmann@griffith.edu.au (A.H.) \\ 2 Queensland Herbarium, Brisbane Botanic Gardens, Toowong, QLD 4066, Australia; \\ paul.forster@des.qld.gov.au (P.I.F.); gordon.guymer@des.qld.gov.au (G.P.G.) \\ 3 Department of Veterinary Biosciences, Melbourne Veterinary School, The University of Melbourne, \\ Melbourne, VIC 3010, Australia \\ * Correspondence: r.davis@griffith.edu.au; Tel.: +61-7-3735-6043; Fax: +61-7-3735-6001
}

Received: 1 February 2019; Accepted: 20 February 2019; Published: 28 February 2019

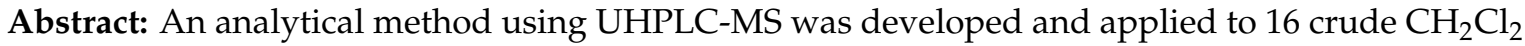
extracts from Australian Celastraceae plants; the endemic plant materials were accessed from Griffith University's NatureBank resource and included bark, fruit, leaf, root, twig and mixed samples, all of which were collected from Queensland, Australia. The generated UHPLC-MS data were analysed and dereplicated using the scientific databases Dictionary of Natural Products and SciFinder Scholar in order to potentially identify new dihydro- $\beta$-agarofurans from local Celastraceae plants. These investigations led to the large-scale extraction and isolation work on a prioritised fruit sample that belonged to the rainforest plant Denhamia celastroides. Chemical investigations resulted in the purification of four new natural products, denhaminols $\mathrm{O}-\mathrm{R}(\mathbf{1 - 4})$, along with the related and known compound, denhaminol $\mathrm{G}(5)$. The structures of all the new compounds were determined via detailed analysis of NMR and MS data.
\end{abstract}

Keywords: UHPLC-MS; Celastraceae; dihydro- $\beta$-agarofuran; sesquiterpenoid; Denhamia celastroides; NMR

\section{Introduction}

Dihydro- $\beta$-agarofurans are a class of structurally unique polyoxygenated tricyclic sesquiterpenoids, which incorporate a trans-decalin and a tetrahydrofuran and are commonly found in the Celastraceae plant family [1]. This class of natural products has gained much attention due to their various and promising bioactivities, such as multidrug resistance reversal [2], antitumor-promotion [3], acetylcholinesterase inhibition [4], antifungal [5], $\alpha$-glucosidase inhibition [6], antiplasmodial [7] and leucine uptake inhibition [8]. The biological effects of dihydro- $\beta$-agarofurans are related not only to several stereocentres but also to acyl groups attached to the tricyclic core scaffold. One of our group's current research interests is the isolation of new natural products (i.e., dihydro- $\beta$-agarofurans) from Australian Celastraceae native plants [8-10].

Within the workflow of natural product research, the time-consuming re-isolation of previously identified compounds presents a major obstacle and can significantly delay discovery efforts [11]. However, rapid and detailed dereplication methodologies can solve this problem. In the context of our continuing interest in the identification of new natural products from Celastraceae plants [8-10], 
we sought to establish a new UHPLC-MS dereplication method that can guide prioritisation of biota samples and expedite the discovery of new secondary metabolites.

UHPLC-MS is becoming an important tool in natural product dereplication as it allows for fast fingerprinting and profiling analysis [12-14]. Moreover, the use of MS in conjunction with the UHPLC system also provides key structural information, such as molecular weight and diagnostic fragments $[12,15,16]$. Therefore, in the current work we utilised UHPLC-MS and scientific database (Dictionary of Natural Products [17] and SciFinder Scholar [18]) analysis to rapidly undertake dereplication and prioritise Australian Celastraceae plant samples for detailed chemical investigation work, with the ultimate goal of identifying new dihydro- $\beta$-agarofurans. The Celastraceae plants used for these studies were all accessed from NatureBank, which is a unique biodiscovery resource based on natural products derived from Australian plants, fungi and marine invertebrates. This facility is located at the Griffith Institute for Drug Discovery (Griffith University) and currently holds an 18,000 extract library, a 90,000 fraction library and $>30,000$ archived biota samples [19]. The 16 NatureBank plant samples used in these particular studies included three bark, one fruit, one leaf, seven root, two twig and two mixed samples collected from Queensland, Australia. The $\mathrm{CH}_{2} \mathrm{Cl}_{2}$ extracts of all 16 plant samples were subjected to UHPLC-MS. A total of three samples were prioritised for potential large-scale extraction and isolation studies; specifically, the selected samples included the fruits of Denhamia celastroides since UHPLC-MS data in conjunction with database analyses suggested the presence of new dihydro- $\beta$-agarofurans. Large-scale extraction and MS-guided isolation of the fruits of $D$. celastroides led to the discovery of four previously undescribed dihydro- $\beta$-agarofurans (denhaminols $\mathrm{O}-\mathrm{R}, 1-4)$ and a known congener denhaminol G (5). The structures of all new compounds were assigned by $1 \mathrm{D} / 2 \mathrm{D}$ NMR and MS data analysis.

This report describes a simple and rapid method for the generation of Celastraceae plant extracts and subsequent UHPLC-MS analysis, dereplication and prioritisation that has successfully led to the identification of four new plant secondary metabolites.

\section{Results and Discussion}

The $\mathrm{CH}_{2} \mathrm{Cl}_{2}$ extracts of samples from 16 Australian Celastraceae plants were prepared using a small amount of the air-dried and ground samples. All extracts were subjected to UHPLC-MS profiling (Figure 1 and Figure S1, Supplementary data) and the molecular masses of the major UV-active compounds in each of the extracts were determined from either the negative or positive total ion chromatogram (TIC). These data were then analysed using SciFinder Scholar and the Dictionary of Natural Products (DNP). Examination of respective UHPLC chromatograms and scientific databases provided a preliminary overview of the constituents of the extracts. The number of hits (from the database search) of the molecular weights generated from the MS data was used as a filter. Of the 16 plant extracts subjected to UHPLC-MS, three plant samples [Denhamia celastroides (F. Muell.) Jessup - fruits, Hysophila halleyana (F. Muell.) - bark and Perrottetia arborescens (F. Muell.) Loes - root] were prioritised since distinct molecular ions were detected (less than five hits reported in the databases; Table S2, Supplementary data). Since the UHPLC traces of the fruit extract of $D$. celastroides showed the best separation amongst all analysed plant extracts (Figure 2), this sample was chosen for additional chemical investigations.

The scientific databases search (Table 1 and Table S2, Supplementary data) indicated the possibility of new dihydro- $\beta$-agarofurans present in the fruits of a Denhamia celastroides $\mathrm{CH}_{2} \mathrm{Cl}_{2}$ extract since it contained several distinct molecular ions in the (+)-ESI mode $\left(m / z 615[\mathrm{M}+\mathrm{H}]^{+} ; 631[\mathrm{M}+\mathrm{H}]^{+}\right.$; and $657[\mathrm{M}+\mathrm{H}]^{+}$), which were only found to match a few dihydro- $\beta$-agarofurans (less than five hits) reported in SciFinder Scholar and DNP search (keywords: "Celastraceae" and "agarofuran"). To confirm the presence of the new compounds and to unambiguously identify the structures, we conducted a large-scale extraction of the plant material and MS-directed purification to isolate the targeted compounds with the distinct molecular weights before NMR experiments were conducted. 


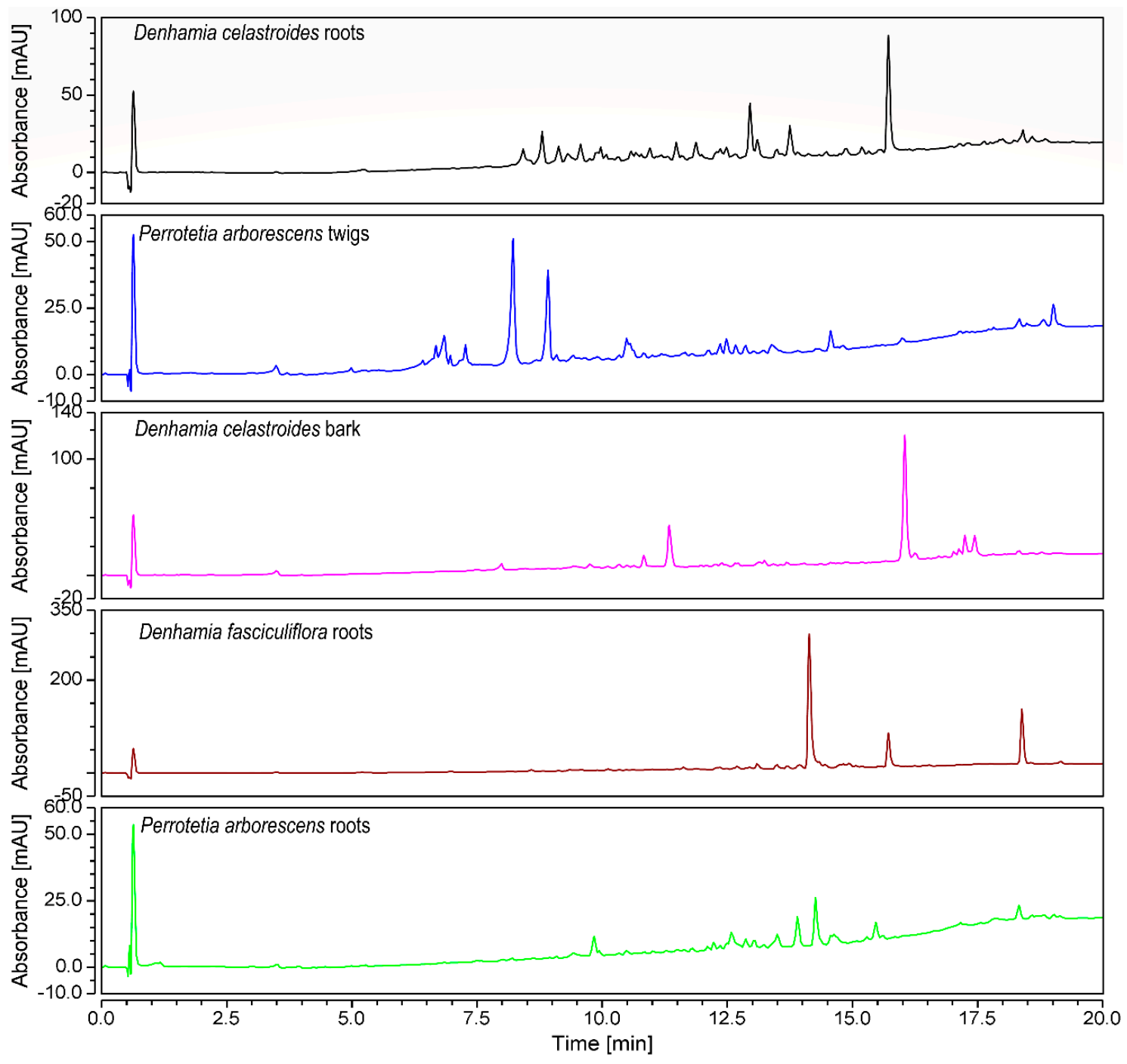

Figure 1. Five representative UHPLC chromatograms $(254 \mathrm{~nm})$ of the 16 Celastraceae plants $\mathrm{CH}_{2} \mathrm{Cl}_{2}$ extracts (for all chromatograms see Figure S1, Supplementary data).

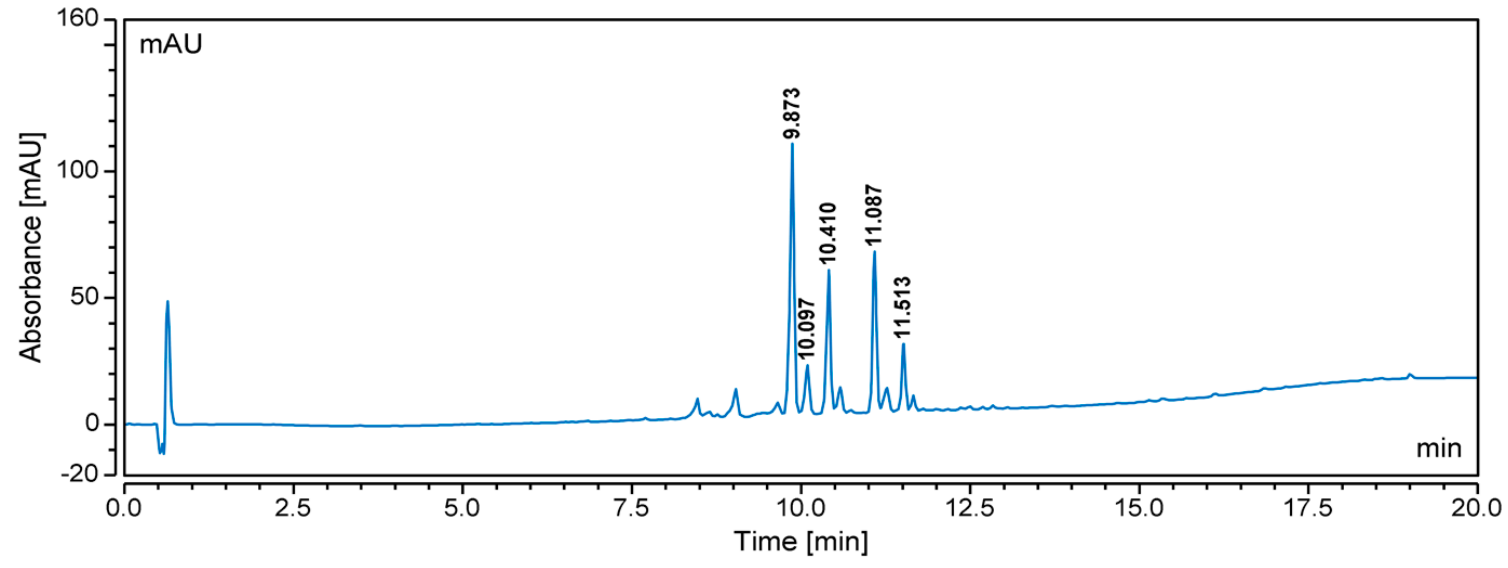

Figure 2. UHPLC chromatogram $(254 \mathrm{~nm})$ of the $\mathrm{CH}_{2} \mathrm{Cl}_{2}$ extract of D. celastroides fruits; retention times for major UV peaks are indicated. 
Table 1. UHPLC-MS data of dihydro- $\beta$-agarofurans from $D$. celastroides fruits and scientific database analysis.

\begin{tabular}{cccccc}
\hline $\begin{array}{c}\text { Retention } \\
\text { Time }\left(\boldsymbol{t}_{\mathbf{R}}, \mathbf{m i n}\right)\end{array}$ & $\begin{array}{c}{[\mathbf{M}+\mathbf{H}]^{+}} \\
\boldsymbol{m} / \boldsymbol{z}\end{array}$ & $\begin{array}{c}\text { Molecular } \\
\text { Weight }\end{array}$ & $\begin{array}{c}\text { No. of SciFinder } \\
\text { Scholar Hits } \mathbf{a}^{\mathbf{2}}\end{array}$ & $\begin{array}{c}\text { No. of DNP } \\
\text { Hits }^{\mathbf{a}}\end{array}$ & Compounds $^{\mathbf{b}}$ \\
\hline 9.873 & 615 & 614 & 1 & 0 & Denhaminol O (1) \\
10.097 & 657 & 656 & 0 & 0 & Denhaminol P (2) \\
10.410 & 673 & 672 & 10 & 0 & Denhaminol G (5) \\
11.087 & 631 & 630 & 4 & 0 & Denhaminol Q (3) \\
11.513 & 653 & 652 & 17 & 0 & Denhaminol R (4) \\
\hline \multicolumn{4}{c}{ a Accessed on the 15 June 2018. ${ }^{\mathrm{b}}$ Trivial names for new compounds identified during these studies. }
\end{tabular}

The fruits of $D$. celastroides $(10 \mathrm{~g})$ were sequentially extracted with $\mathrm{CH}_{2} \mathrm{Cl}_{2}$. Subsequent purifications using silica gel column chromatography and RP-HPLC afforded five dihydro- $\beta$ agarofurans (Figure 3). The targeted compounds with molecular ions $m / z[\mathrm{M}+\mathrm{H}]^{+}$of 615,631 and 657 were confirmed to be new natural products, which were given the trivial name denhaminols $\mathrm{O}-\mathrm{Q}(\mathbf{1}-\mathbf{3})$, respectively. During the isolation of the three targeted compounds, another new dihydro- $\beta$-agarofuran (denhaminol R, 4) and a known congener, denhaminol G (5) [20] were also obtained. The complete structure elucidation of the new compounds is detailed below.

Denhaminol O (1) was isolated as a colourless gum with a molecular formula of $\mathrm{C}_{33} \mathrm{H}_{42} \mathrm{O}_{11}$ as assigned by HRESIMS data $\left(m / z\right.$ 637.2595). The ${ }^{1} \mathrm{H}-\mathrm{NMR}$ spectrum (Table 2$)$ exhibited signals of 6 methyl protons $\left(\delta_{\mathrm{H}} 1.33,1.59,1.63,1.78,1.79\right.$ and 1.88$), 5$ methylene protons $\left(\delta_{\mathrm{H}} 1.53 / 1.95,1.69 / 1.86\right.$, $2.03 / 2.26,4.31 / 4.45$ and $4.52 / 4.69)$ and 12 methine protons $\left(\delta_{H} 2.37,4.44,4.88,5.39,6.40,6.81,7.36\right.$ $(3 \mathrm{H}), 7.56(2 \mathrm{H})$ and 7.65$)$. The ${ }^{13} \mathrm{C}$ (Table 3$)$ and HSQC spectra of 1 suggested a total of 33 carbons, including 6 methyls, 5 methylenes, 12 methines and 10 non-protonated carbons. The ${ }^{13} \mathrm{C}$ resonances at $\delta_{C} 165.9,167.1,167.6$ and 170.2 suggested the presence of four ester groups in 1 . These data indicated that compound 1 was a dihydro- $\beta$-agarofuran bearing four ester groups [8-10], which was confirmed by COSY and HMBC experiments (Figure 4).

The positions of the ester groups were determined following HMBC data analysis. HMBC cross-peaks from two olefinic protons $\left(\delta_{\mathrm{H}} 6.40\right.$ and $\left.7.65, \mathrm{~d}, J=16.0\right)$ and $\mathrm{H}-9\left(\delta_{\mathrm{H}} 4.88\right)$ to an ester carbonyl carbon at $\delta_{\mathrm{H}} 165.9$ located a trans-cinnamate group at C-9. The ${ }^{1} \mathrm{H}-\mathrm{NMR}$ resonances at $\delta_{\mathrm{H}}$ $1.78(3 \mathrm{H}, \mathrm{m}), 1.79(3 \mathrm{H}, \mathrm{m})$ and $6.81(1 \mathrm{H}, \mathrm{m})$ were the characteristic of tigloyl moiety [20]. The tigloyl group was located at $\mathrm{C}-12$ based on $\mathrm{HMBC}$ correlations from a pair of diastereotopic methylene protons $\left(\delta_{\mathrm{H}} 4.52\right.$ and 4.69$)$, a methyl at $\delta_{\mathrm{H}} 1.79$ and an olefinic proton at $\delta_{\mathrm{H}} 6.81$ to a carbonyl resonance at $\delta_{C}$ 167.6. The HMBC spectrum of 1 also exhibited correlations from a set of methylene protons at $\delta_{\mathrm{H}} 4.31$ and 4.45 to two carbonyl carbons resonating at $\delta_{\mathrm{C}} 167.1$ and 170.2. These data along with further HMBC correlation from $\mathrm{H}-1\left(\delta_{\mathrm{H}} 4.88\right)$ to the carbonyl carbon at 167.1 suggested the location of an acetoxyacetate functional group at C-1. Finally, two hydroxy moieties were positioned at C- 4 and C- 6 by considering the molecular formula of 1 and the deshielded NMR resonances of $\mathrm{C}-4\left(\delta_{\mathrm{C}} 73.3\right)$ and $\mathrm{CH}-6\left(\delta_{\mathrm{H}} 4.44\right.$ and $\left.\delta_{\mathrm{C}} 79.4\right)$. The relative configuration of denhaminol O (1) was established by ROESY (Figure 4) and ${ }^{1} \mathrm{H}^{-}{ }^{1} \mathrm{H}$ coupling constant data analysis. The large coupling constant of H-1 $\left(J_{1,2}=12.1 \mathrm{~Hz}\right)$ indicated the $\beta$-orientation of H-1. Similarly, the $\alpha$-orientation of $\mathrm{H}-9$ was assigned based on the coupling constant $\left(J_{8,9}=7.4 \mathrm{~Hz}\right)$. ROESY cross-peaks between $\mathrm{H}_{3}-14$ and $\mathrm{H}-6$ and between $\mathrm{H}-6$ and $\mathrm{H}-9$ as well as between $\mathrm{H}-9$ and $\mathrm{H}_{3}-15$ suggested that these protons were cofacial. It is worth mentioning that ROESY correlations were also observed between $\mathrm{H}_{2}-12$ and $\mathrm{H}-8 \beta$ as well as between $\mathrm{H}_{3}-13$ and $\mathrm{H}-7$. Consequently, the structure of $\mathbf{1}$ was established as $1 \alpha$-acetoxyacetate- $8 \beta$-cinnamoyloxy- $4 \beta, 6 \beta$-dihydroxy-12-tigloyloxydihydro- $\beta$-agarofuran. 


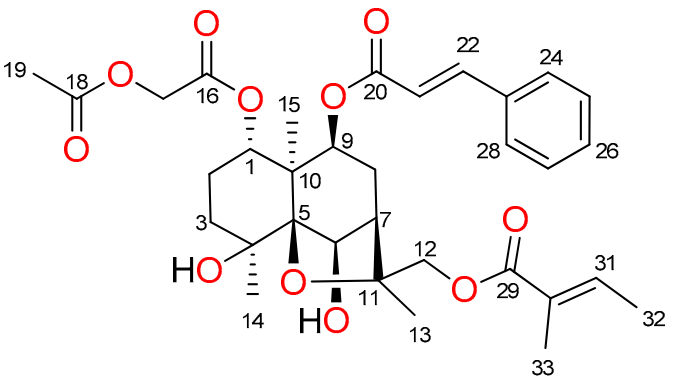

1

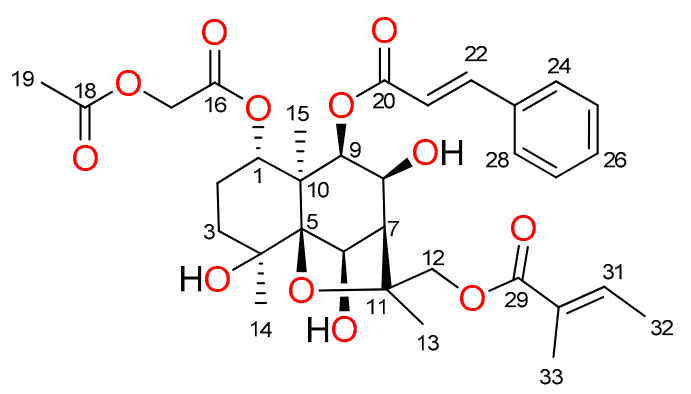

3

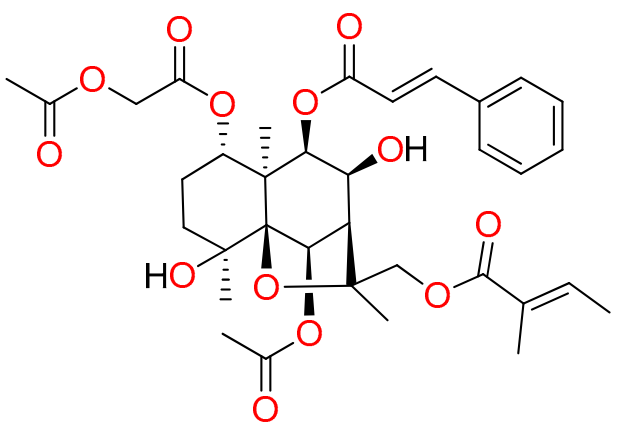

5

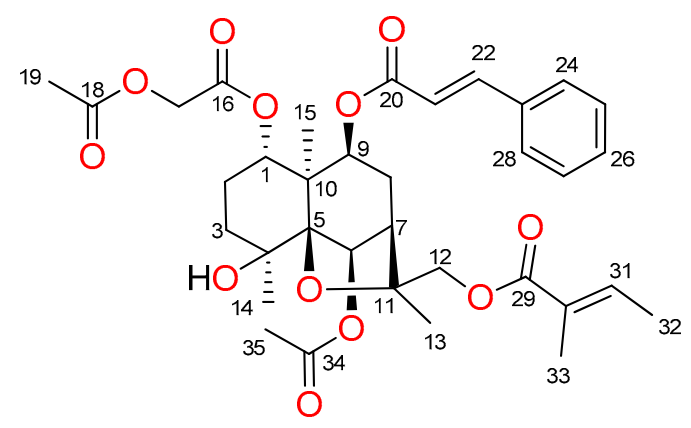

2

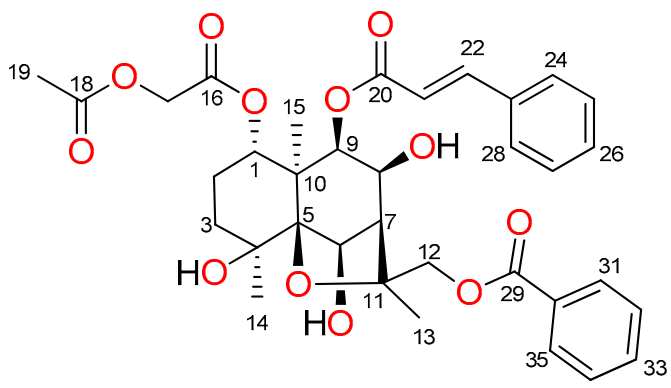

4

Figure 3. Chemical structures of denhaminols O-R (1-4) and denhaminol G (5).

Denhaminol P (2, colourless gum) had a molecular formula of $\mathrm{C}_{35} \mathrm{H}_{44} \mathrm{O}_{12}$ as assigned by (+)-HRESIMS. Comparison of ${ }^{1} \mathrm{H}$ and ${ }^{13} \mathrm{C}-\mathrm{NMR}$ spectra of $\mathbf{2}$ and $\mathbf{1}$ showed a high degree of similarity between the two compounds. However, the ${ }^{1} \mathrm{H}$ resonance of H-6 was shifted downfield from $\delta_{\mathrm{H}} 4.44$ in 1 to $\delta_{\mathrm{H}} 5.48$ in 2, which suggested the attachment of an ester group at C-6 in 2. HMBC correlations from a methyl singlet signal at $\delta_{\mathrm{H}} 2.15$ and $\mathrm{H}-6\left(\delta_{\mathrm{H}} 5.48\right)$ to a carbonyl carbon at $\delta_{\mathrm{C}} 170.6$ identified the presence of an acetate group at C-6 in 2. The 2D NMR data (Figure S28, Supplementary data) further confirmed the attachment of the remaining ester moieties in 2. Comparison of ROESY data of $\mathbf{1}$ and $\mathbf{2}$ revealed the same relative configurations for these compounds. Thus, the structure of 2 was elucidated as $6 \beta$-acetoxy- $1 \alpha$-acetoxyacetate- $8 \beta$-cinnamoyloxy- $4 \beta$-hydroxy-12-tigloyloxydihydro- $\beta$-agarofuran. 

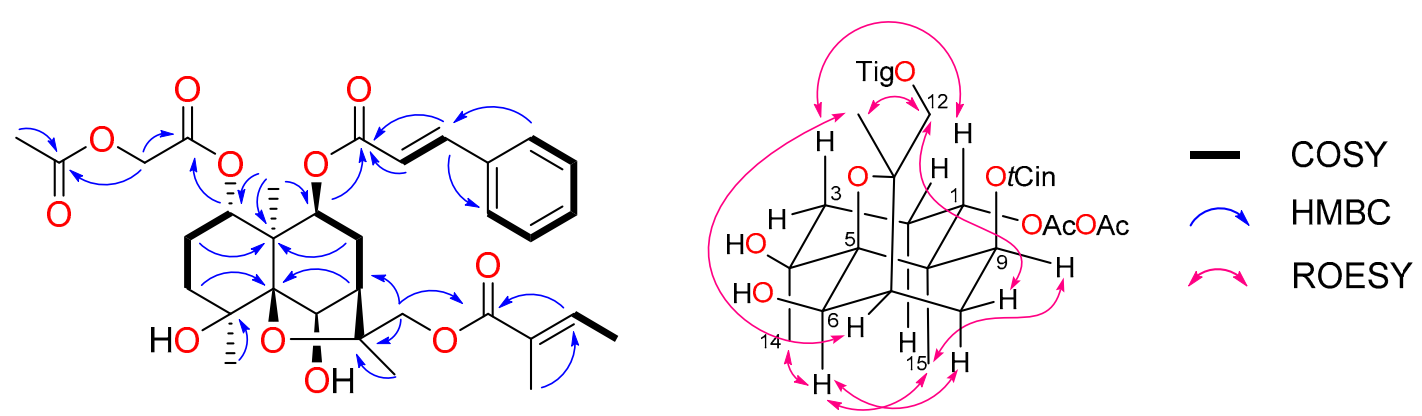

Figure 4. Diagnostic 2D NMR correlations for denhaminol O (1).

Table 2. ${ }^{1} \mathrm{H}(800 \mathrm{MHz})$ NMR data for denhaminols O-R (1-4) in $\mathrm{CDCl}_{3}$.

\begin{tabular}{|c|c|c|c|c|}
\hline \multirow{2}{*}{ Position } & \multicolumn{4}{|c|}{$\delta_{\mathrm{H}}$, multiplicity $(J$ in $\mathrm{Hz})$} \\
\hline & 1 & 2 & 3 & 4 \\
\hline 1 & $5.39, \mathrm{dd}(12.1,4.5)$ & 5.36, dd $(12.1,4.2)$ & $5.40, \mathrm{dd}(12.1,4.4)$ & 5.46, dd $(12.1,4.4)$ \\
\hline $2 \alpha$ & $1.53, \mathrm{~m}$ & $1.51, \mathrm{~m}$ & $1.52, \mathrm{~m}$ & $1.54, \mathrm{~m}$ \\
\hline $2 \beta$ & $1.95, \mathrm{~m}$ & $1.91, \mathrm{~m}$ & $1.95, \mathrm{~m}$ & $1.98, \mathrm{~m}$ \\
\hline $3 \alpha$ & 1.69, ddd $(13.1,3.4,3.4)$ & 1.68, ddd $(13.5,3.3,3.3)$ & 1.68, ddd $(13.0,3.2,3.2)$ & $1.71, \mathrm{ddd}(13.1,3.4,3.4)$ \\
\hline $3 \beta$ & $1.86, \mathrm{~m}$ & $1.86, \mathrm{~m}$ & $1.84, \mathrm{~m}$ & $1.88, \mathrm{~m}$ \\
\hline 6 & 4.44, br s & $5.48, \mathrm{~s}$ & 4.37 , br s & 4.42, br s \\
\hline 7 & 2.37, br dd $(3.5,3.0)$ & 2.34, br dd $(3.6,3.0)$ & 2.64, br d (3.2) & 2.73, br d (3.3) \\
\hline $8 \alpha$ & 2.26 , ddd $(16.6,7.4,3.5)$ & 2.46, ddd $(16.6,7.3,3.6)$ & 4.30 , dd $(6.4,3.2)$ & 4.35 , dd $(6.5,3.3)$ \\
\hline $8 \beta$ & $2.03, \mathrm{dd}(16.6,3.0)$ & $2.12, \mathrm{~m}$ & - & - \\
\hline 9 & $4.88, \mathrm{~d}(7.4)$ & $4.92, \mathrm{~d}(7.0)$ & $5.06, \mathrm{~d}(6.4)$ & $5.08, \mathrm{~d}(6.5)$ \\
\hline & $4.52, \mathrm{~d}(11.0)$ & $4.47, \mathrm{~d}(11.1)$ & $4.69, \mathrm{~d}(11.6)$ & $4.88, \mathrm{~d}(11.5)$ \\
\hline 12 & $4.69, \mathrm{~d}(11.0)$ & $4.70, \mathrm{~d}(11.1)$ & $4.82, \mathrm{~d}(11.6)$ & $5.02, \mathrm{~d}(11.5)$ \\
\hline 13 & $1.63, \mathrm{~s}$ & $1.58, \mathrm{~s}$ & $1.65, \mathrm{~s}$ & $1.76, \mathrm{~s}$ \\
\hline 14 & $1.59, \mathrm{~s}$ & $1.33, \mathrm{~s}$ & $1.57, \mathrm{~s}$ & $1.60, \mathrm{~s}$ \\
\hline 15 & $1.33, \mathrm{~s}$ & $1.36, \mathrm{~s}$ & $1.32, \mathrm{~s}$ & $1.35, \mathrm{~s}$ \\
\hline & $4.31, \mathrm{~d}(15.9)$ & $4.33(15.8)$ & $4.33, \mathrm{~d}(15.8)$ & $4.34, \mathrm{~d}(15.9)$ \\
\hline 17 & $4.45, \mathrm{~d}(15.9)$ & $4.46(15.8)$ & $4.47, \mathrm{~d}(15.8)$ & $4.47, \mathrm{~d}(15.9)$ \\
\hline 19 & $1.88, \mathrm{~s}$ & $1.91, \mathrm{~s}$ & $1.92, \mathrm{~s}$ & $1.91, \mathrm{~s}$ \\
\hline 21 & $6.40, \mathrm{~d}(16.0)$ & $6.39, \mathrm{~d}(16.0)$ & $6.49, \mathrm{~d}(15.9)$ & $6.54, \mathrm{~d}(16.0)$ \\
\hline 22 & $7.65, \mathrm{~d}(16.0)$ & $7.66, \mathrm{~d}(16.0)$ & $7.69, \mathrm{~d}(15.9)$ & $7.71, \mathrm{~d}(16.0)$ \\
\hline 24 & $7.56, \mathrm{~m}$ & $7.56, \mathrm{~m}$ & $7.58, \mathrm{~m}$ & $7.54, \mathrm{~m}$ \\
\hline 25 & $7.36, \mathrm{~m}$ & $7.37, \mathrm{~m}$ & $7.36, \mathrm{~m}$ & 7.33, $\mathrm{m}$ \\
\hline 26 & $7.36, \mathrm{~m}$ & $7.37, \mathrm{~m}$ & $7.36, \mathrm{~m}$ & $7.36, \mathrm{~m}$ \\
\hline 27 & $7.36, \mathrm{~m}$ & $7.37, \mathrm{~m}$ & $7.36, \mathrm{~m}$ & $7.33, \mathrm{~m}$ \\
\hline 28 & $7.56, \mathrm{~m}$ & $7.56, \mathrm{~m}$ & $7.58, \mathrm{~m}$ & $7.54, \mathrm{~m}$ \\
\hline 31 & $6.81, \mathrm{~m}$ & 6.81, $\mathrm{m}$ & $6.85, \mathrm{~m}$ & $8.03, \mathrm{~m}$ \\
\hline 32 & $1.78, \mathrm{~m}$ & $1.78, \mathrm{~m}$ & $1.80, \mathrm{~m}$ & $7.45, \mathrm{~m}$ \\
\hline 33 & $1.79, \mathrm{~m}$ & $1.78, \mathrm{~m}$ & $1.82, \mathrm{~m}$ & $7.57, \mathrm{~m}$ \\
\hline 34 & - & - & $\begin{array}{l}1.02,111 \\
-\end{array}$ & $7.45, \mathrm{~m}$ \\
\hline 35 & - & $2.15, \mathrm{~s}$ & - & $8.03, \mathrm{~m}$ \\
\hline
\end{tabular}

Compound 3 was isolated as a colourless gum and had a molecular formula of $\mathrm{C}_{33} \mathrm{H}_{42} \mathrm{O}_{12}$ as suggested by HRESIMS. The NMR data of $\mathbf{3}$ were similar to those of $\mathbf{1}$, except for the presence of an additional hydroxy in 3 . The hydroxy group was positioned at C-8 based on the deshielded resonances of $\mathrm{CH}-8\left(\delta_{\mathrm{H}} 4.30\right.$ and $\left.\delta_{\mathrm{C}} 70.3\right)$. HMBC correlations (Figure S29, Supplementary data) from $\mathrm{H}-8$ to $\mathrm{C}-6, \mathrm{C}-9$ and $\mathrm{C}-11$ further confirmed the location of $\mathrm{OH}-8$. The $\beta$-orientation of the hydroxy moiety at C-8 was assigned by ROESY correlations (Figure S29, Supplementary data) between $\mathrm{H}-8$ and $\mathrm{H}_{3}-15$. Therefore, the structure of denhaminol Q (3) was determined as $1 \alpha$-acetoxyacetate-8 $\beta$-cinnamoyloxy- $4 \beta, 6 \beta, 8 \beta$-trihydroxy-12-tigloyloxydihydro- $\beta$-agarofuran. 
Table 3. ${ }^{13} \mathrm{C}(200 \mathrm{MHz}) \mathrm{NMR}$ data for denhaminols $\mathrm{O}-\mathrm{R}(\mathbf{1}-\mathbf{4})$ in $\mathrm{CDCl}_{3}$.

\begin{tabular}{|c|c|c|c|c|}
\hline \multirow{2}{*}{ Position } & \multicolumn{4}{|c|}{$\delta_{\mathrm{H}}$, Type } \\
\hline & 1 & 2 & 3 & 4 \\
\hline 1 & $73.2,{ }^{*} \mathrm{CH}$ & $73.5, \mathrm{CH}$ & $73.2,{ }^{*} \mathrm{CH}$ & $73.2,{ }^{*} \mathrm{CH}$ \\
\hline 2 & $23.5, \mathrm{CH}_{2}$ & 23.6, $\mathrm{CH}_{2}$ & 23.3, $\mathrm{CH}_{2}$ & 23.3, $\mathrm{CH}_{2}$ \\
\hline 3 & $36.9, \mathrm{CH}_{2}$ & $38.3, \mathrm{CH}_{2}$ & $37.0, \mathrm{CH}_{2}$ & $37.0, \mathrm{CH}_{2}$ \\
\hline 4 & $73.3{ }^{*} \mathrm{C}$ & $70.6, \mathrm{C}$ & $73.3,{ }^{*} \mathrm{CH}$ & $73.3,{ }^{*} \mathrm{CH}$ \\
\hline 5 & $92.4, \mathrm{C}$ & $92.4, \mathrm{C}$ & $91.8, \mathrm{C}$ & $91.9, \mathrm{C}$ \\
\hline 6 & $79.4, \mathrm{CH}$ & $79.4, \mathrm{CH}$ & $78.0, \mathrm{CH}$ & $78.0, \mathrm{CH}$ \\
\hline 7 & $49.0, \mathrm{CH}$ & $48.0, \mathrm{CH}$ & $56.0, \mathrm{CH}$ & $55.9, \mathrm{CH}$ \\
\hline 8 & $31.7, \mathrm{CH}_{2}$ & $31.8, \mathrm{CH}_{2}$ & $70.3, \mathrm{CH}$ & $70.5, \mathrm{CH}$ \\
\hline 9 & $72.1, \mathrm{CH}$ & 72.0, $\mathrm{CH}$ & $74.4, \mathrm{CH}$ & $74.6, \mathrm{CH}$ \\
\hline 10 & $50.3, \mathrm{C}$ & $51.6, \mathrm{C}$ & 48.7, C & $48.8, \mathrm{C}$ \\
\hline 11 & $84.9, \mathrm{C}$ & $84.8, \mathrm{C}$ & $85.5, \mathrm{C}$ & $85.6, \mathrm{C}$ \\
\hline 12 & 69.4, $\mathrm{CH}_{2}$ & $68.8, \mathrm{CH}_{2}$ & $69.8, \mathrm{CH}_{2}$ & $70.3, \mathrm{CH}_{2}$ \\
\hline 13 & $25.1, \mathrm{CH}_{3}$ & 24.7, $\mathrm{CH}_{3}$ & $24.9, \mathrm{CH}_{3}$ & $24.9, \mathrm{CH}_{3}$ \\
\hline 14 & $23.8, \mathrm{CH}_{3}$ & $24.2, \mathrm{CH}_{3}$ & $23.8, \mathrm{CH}_{3}$ & $23.8, \mathrm{CH}_{3}$ \\
\hline 15 & $20.0, \mathrm{CH}_{3}$ & $19.8, \mathrm{CH}_{3}$ & $20.1, \mathrm{CH}_{3}$ & $20.2, \mathrm{CH}_{3}$ \\
\hline 16 & 167.1, C & 167.1, C & 167.1, C & 167.1, C \\
\hline 17 & $60.8, \mathrm{CH}_{2}$ & $60.8, \mathrm{CH}_{2}$ & $60.8, \mathrm{CH}_{2}$ & $60.8, \mathrm{CH}_{2}$ \\
\hline 18 & $170.2, \mathrm{C}$ & $170.2, \mathrm{C}$ & $170.2, \mathrm{C}$ & $170.2, \mathrm{C}$ \\
\hline 19 & $20.3, \mathrm{CH}_{3}$ & $20.4, \mathrm{CH}_{3}$ & $20.3, \mathrm{CH}_{3}$ & $20.3, \mathrm{CH}_{3}$ \\
\hline 20 & $165.9, \mathrm{C}$ & $166.0, \mathrm{C}$ & 167.6, C & $167.9, \mathrm{C}$ \\
\hline 21 & 117.7, CH & 117.0, $\mathrm{CH}$ & $117.5, \mathrm{CH}$ & $117.3, \mathrm{CH}$ \\
\hline 22 & $146.2, \mathrm{CH}$ & $146.3, \mathrm{CH}$ & $146.9, \mathrm{CH}$ & 147.1, CH \\
\hline 23 & $134.6, \mathrm{C}$ & $134.6, \mathrm{C}$ & 134.6, C & $134.5, \mathrm{C}$ \\
\hline 24 & 128.6, $\mathrm{CH}$ & $128.7, \mathrm{CH}$ & $128.7, \mathrm{CH}$ & $128.76, \mathrm{CH}$ \\
\hline 25 & $128.8, \mathrm{CH}$ & $128.8, \mathrm{CH}$ & $128.9, \mathrm{CH}$ & $128.83, \mathrm{CH}$ \\
\hline 26 & $130.4, \mathrm{CH}$ & $130.5, \mathrm{CH}$ & $130.5, \mathrm{CH}$ & $130.6, \mathrm{CH}$ \\
\hline 27 & $128.8, \mathrm{CH}$ & $128.8, \mathrm{CH}$ & $128.9, \mathrm{CH}$ & $128.83, \mathrm{CH}$ \\
\hline 28 & 128.6, $\mathrm{CH}$ & $128.7, \mathrm{CH}$ & 128.7, $\mathrm{CH}$ & $128.76, \mathrm{CH}$ \\
\hline 29 & 167.6, C & $127.5, \mathrm{C}$ & 167.9, C & $166.4, \mathrm{C}$ \\
\hline 30 & $128.5, \mathrm{C}$ & $128.4, \mathrm{C}$ & $128.8, \mathrm{C}$ & $130.5, \mathrm{C}$ \\
\hline 31 & 137.7, $\mathrm{CH}$ & $137.9, \mathrm{CH}$ & $137.5, \mathrm{CH}$ & $129.8, \mathrm{CH}$ \\
\hline 32 & $14.5, \mathrm{CH}_{3}$ & 14.6, $\mathrm{CH}_{3}$ & $14.5, \mathrm{CH}_{3}$ & $128.5, \mathrm{CH}$ \\
\hline 33 & $12.2, \mathrm{CH}_{3}$ & $12.2, \mathrm{CH}_{3}$ & $12.2, \mathrm{CH}_{3}$ & 133.1, CH \\
\hline 34 & - & $170.6, \mathrm{C}$ & - & $128.5, \mathrm{CH}$ \\
\hline 35 & - & $21.8, \mathrm{CH}_{3}$ & - & $129.8, \mathrm{CH}$ \\
\hline
\end{tabular}

During the isolation of the major compounds 1-3, denhaminol R (4) was obtained. The molecular formula of compound 4 was $\mathrm{C}_{35} \mathrm{H}_{40} \mathrm{O}_{12}$ as indicated by (+)-HRESIMS data. Analysis of NMR and MS data showed that the structure of 4 was similar to that of 3 . However, the tigloyl group at C-12 in 3 was replaced by a benzoate in 4 . The presence of the benzoate group was confirmed by the characteristic ${ }^{1} \mathrm{H}$ NMR resonances at $\delta_{\mathrm{H}} 7.45(2 \mathrm{H}, \mathrm{m}), 7.57(1 \mathrm{H}, \mathrm{m})$ and 8.03 $(2 \mathrm{H}, \mathrm{m})$. The position of the benzoate at $\mathrm{C}-12$ was assigned by HMBC correlations (Figure S30, Supplementary data) from $\mathrm{H}_{2}-12\left(\delta_{\mathrm{H}} 4.88\right.$ and 5.02) and the proton at $\delta_{\mathrm{H}} 8.03$ to an ester carbonyl carbon at $\delta_{C} 166.4$. The relative configurations of 4 were ascertained to be the same as those of 3 by ROESY experiment. Accordingly, the structure compound 4 was assigned as $1 \alpha$-acetoxyacetate-12-benzoylyloxy- $8 \beta$-cinnamoyloxy- $4 \beta, 6 \beta, 8 \beta$-trihydroxydihydro- $\beta$-agarofuran.

Previously, we reported the isolation of dihydro- $\beta$-agarofuran sesquiterpenoids from two Australian plants belonging to the Denhamia genus, namely D. celastroides and D. pittosporoides. The chemical investigation of the leaves of $D$. celastroides afforded eight dihydro- $\beta$-agarofurans (denhaminol A-H) [20], while two new dihydro- $\beta$-agarofurans (denhaminols I and J) were obtained from the leaves of $D$. pittosporoides [9]. 


\section{Materials and Methods}

\subsection{General Experimental Procedures}

Values of specific rotations were determined with a JASCO P-1020 polarimeter and UV spectra were recorded using a JASCO V-650 UV/vis spectrophotometer (ATA Scientific, Taren Point, NSW, Australia). ECD spectra were obtained on a JASCO J-715 spectropolarimeter (Tokyo, Japan) and processed using the software SDAR v3.2 [21]. IR data were acquired using an attached universal attenuated total reflectance (UATR) two module on a PerkinElmer spectrophotometer (Waltham, MA, USA). NMR spectra were acquired from a Bruker AVANCE HDX $800 \mathrm{MHz}$ NMR spectrometer (Zurich, Switzerland) equipped with a TCI cryoprobe at $25{ }^{\circ} \mathrm{C}$. The ${ }^{1} \mathrm{H}$ and ${ }^{13} \mathrm{C}$ chemical shifts were referenced to the residual solvent signal of $\mathrm{CDCl}_{3}$ at $\delta_{\mathrm{H}} 7.26$ and $\delta_{\mathrm{C}} 77.16 \mathrm{ppm}$, respectively. HRESIMS data were acquired on a Bruker maXis II ETD ESI-qTOF (Bremen, Germany) and the mass spectrum was calibrated externally with $0.1 \mathrm{mg} / \mathrm{mL}$ of sodium trifluoroacetate. A Fritsch Universal Cutting Mill Pulverisette 19 (Idar-Oberstein, Germany) was used to grind the air-dried plant material and an Edwards Instrument Company Bio-line orbital shaker (Narangba, Australia) was used for plant extraction. Phenomenex Strata solid phase extraction (SPE) cartridges (3 cc, polypropylene, single fritted, catalogue\# AH0-7806) (Torrance, California, USA) were used for the small-scale plant extractions. The UHPLC-MS was performed on an Ultimate 3000 RS UHPLC (Waltham, MA, USA) coupled to a Thermo Fisher Scientific MSQ Plus single quadruple ESI mass spectrometer (Waltham, MA, USA) using an analytical Waters ACQUITY UPLC CSH C 18 column $(2.1 \times 50 \mathrm{~mm}, 1.7 \mu \mathrm{m}, 130 \AA$ A) (Milford, MA, USA). A Thermo Fisher Scientific Dionex Ultimate 3000 UHPLC was used for semi-preparative HPLC separations. A Phenomenex Luna $C_{18}(250 \times 10 \mathrm{~mm}, 5 \mu \mathrm{m}, 90-110 \AA)$ column (Torrance, CA, USA) was used for semi-preparative HPLC separations. Alltech $\mathrm{C}_{18}$-bonded Si (35-75 $\mu \mathrm{m}, 150 \AA$ ) (Sydney, NSW, Australia) was used for pre-adsorption work, and the resulting material was packed into an Alltech stainless steel guard cartridge $(10 \times 30 \mathrm{~mm})$ prior to semi-preparative HPLC separations. Merck Si gel (0.040-0.063 mm, 230-400 mesh) (Darmstadt, Germany) was used for Si gel column chromatography. All solvents $\left(\mathrm{CH}_{2} \mathrm{Cl}_{2}\right.$ and $\left.\mathrm{CH}_{3} \mathrm{CN}\right)$ used for chromatography, specific rotation, $\mathrm{ECD}, \mathrm{UV}$ and MS were RCI Labscan HPLC grade (Samutsakhorn, Thailand). $\mathrm{H}_{2} \mathrm{O}$ was Sartorius arium pro VF (Göttingen, Germany) filtered. All compounds were analysed for purity by ${ }^{1} \mathrm{H}$ NMR spectroscopy and shown to be $>95 \%$, unless otherwise stated. NMR spectra were processed using MestReNova version 11.0 (Santiago de Compostela, Spain).

\subsection{Plant Materials}

The 16 Celastraceae plant samples were obtained from the NatureBank biota library housed at the Griffith Institute for Drug Discovery, Griffith University, Australia [19]. All samples were collected in Queensland and taxonomically identified by the Queensland Herbarium. Voucher specimens have been deposited at the Queensland Herbarium, Australia. All plant specimens were air-dried, ground and stored at room temperature prior to extraction. The fruits of Denhamia celastroides (F. Muell.) Jessup (Voucher specimen code: AQ605014) that were used in the large-scale extraction and isolation investigations were collected on 26 November 1997 in Mt Windsor Tableland rainforest, Queensland, Australia. Details of the collection date, location and voucher specimen codes for the other Celastraceae plants used in these studies are provided in Table S31 of the supplementary data.

\subsection{Preparation of Crude Plant Extracts for UHPLC-MS Analyses}

Each of the air-dried and ground Celastraceae plant materials (300 mg) was packed into an SPE cartridge and extracted under gravity with $8 \mathrm{~mL}$ of $\mathrm{CH}_{2} \mathrm{Cl}_{2}$. The $\mathrm{CH}_{2} \mathrm{Cl}_{2}$ extracts were dried, weighed and resuspended in $\mathrm{CH}_{3} \mathrm{CN}$ to generate a stock solution, which had a concentration of $1 \mathrm{mg} / \mathrm{mL}$ (minimum stock solution volume $=0.5 \mathrm{~mL}$ ). 


\subsection{UHPLC-MS Conditions}

All $\mathrm{CH}_{2} \mathrm{Cl}_{2}$ extracts were subjected to UHPLC-MS analysis ( $5 \mu \mathrm{L}$ injection volume). UHPLC-MS experiments were performed with an Ultimate 3000 RS UHPLC coupled to a Thermo Fisher MSQ Plus single quadruple ESI mass spectrometer (Waltham, MA, USA) using an analytical Waters ACQUITY UPLC CSH C 18 column $(2.1 \times 50 \mathrm{~mm}, 1.7 \mu \mathrm{m}, 130 \AA$ ) (Milford, MA, USA). Employing a flowrate of $0.3 \mathrm{~mL} / \mathrm{min}$, a gradient of $10 \% \mathrm{CH}_{3} \mathrm{CN}(0.1 \%$ formic acid $)$ in $\mathrm{H}_{2} \mathrm{O}(0.1 \%$ formic acid $)$ to $100 \% \mathrm{CH}_{3} \mathrm{CN}$ ( $0.1 \%$ formic acid) was applied over $15 \mathrm{~min}$, followed by isocratic elution of $\mathrm{CH}_{3} \mathrm{CN}(0.1 \%$ formic acid).

\subsection{Large-scale Extraction and Isolation of the Fruits of D. celastroides}

The air-dried and ground fruits of D. celastroides $(10 \mathrm{~g})$ were extracted with $\mathrm{CH}_{2} \mathrm{Cl}_{2}(2 \times 500 \mathrm{~mL}$ for $16 \mathrm{~h}$ each) to afford $245.8 \mathrm{mg}$ of a crude extract. The extract was subjected to chromatography using a Si-gel column $(3 \times 8 \mathrm{~cm})$ and a step-wise gradient system of $n$-hexane/EtOAc $(100 \% n$-hexane to $100 \%$ EtOAc, $10 \%$ increment, $100 \mathrm{~mL}$ each) to afford 11 fractions (fractions 1-11). All 11 fractions were analysed by UPLC-MS and fractions 7-9 were chosen for further purification based on UPLC-MS data analysis. Fraction $7(22.4 \mathrm{mg})$ was pre-adsorbed to $C_{18}$ bonded Si-gel $(\sim 1 \mathrm{~g})$, packed into a guard cartridge and attached to a semi-preparative $\mathrm{C}_{18}$ HPLC column. A linear gradient from $45 \% \mathrm{CH}_{3} \mathrm{CN} / \mathrm{H}_{2} \mathrm{O}$ to $90 \% \mathrm{CH}_{3} \mathrm{CN} / \mathrm{H}_{2} \mathrm{O}$ at a flowrate of $4 \mathrm{~mL} / \mathrm{min}$ was run over $60 \mathrm{~min}$ to obtain denhaminol $\mathrm{O}\left(\mathbf{1}, 10.4 \mathrm{mg}, t_{\mathrm{R}} 18-19 \mathrm{~min}, 0.104 \%\right.$ dry $\left.w t\right)$ and denhaminol $\mathrm{Q}\left(\mathbf{2}, 1.5 \mathrm{mg}, t_{\mathrm{R}} 21 \mathrm{~min}\right.$, $0.015 \%$ dry $w t)$. Fraction $8(38.4 \mathrm{mg})$ was pre-adsorbed to $\mathrm{C}_{18}$ bonded Si-gel $(\sim 1 \mathrm{~g})$, packed into a guard cartridge and attached to a semi-preparative $\mathrm{C}_{18}$ HPLC column. A linear gradient from $45 \%$ $\mathrm{CH}_{3} \mathrm{CN} / \mathrm{H}_{2} \mathrm{O}$ to $80 \% \mathrm{CH}_{3} \mathrm{CN} / \mathrm{H}_{2} \mathrm{O}$ at a flowrate of $4 \mathrm{~mL} / \mathrm{min}$ was run over $60 \mathrm{~min}$ to afford the known natural product, denhaminol G (5, $13.9 \mathrm{mg}, t_{\mathrm{R}} 24 \mathrm{~min}, 0.139 \%$ dry $\left.w t\right)$. Fraction $9(29.4 \mathrm{mg})$ was pre-adsorbed to $\mathrm{C}_{18}$ bonded Si-gel $(\sim 1 \mathrm{~g})$, packed into a guard cartridge and attached to a semi-preparative $\mathrm{C}_{18} \mathrm{HPLC}$ column. A linear gradient from $40 \% \mathrm{CH}_{3} \mathrm{CN} / \mathrm{H}_{2} \mathrm{O}$ to $70 \% \mathrm{CH}_{3} \mathrm{CN} / \mathrm{H}_{2} \mathrm{O}$ at a flowrate of $4 \mathrm{~mL} / \mathrm{min}$ was run over $60 \mathrm{~min}$ to yield denhaminol $\mathrm{P}\left(3,10.2 \mathrm{mg}, t_{\mathrm{R}} 27-28 \mathrm{~min}, 0.102 \%\right.$ dry $w t)$ and denhaminol $\mathrm{R}\left(4,2.2 \mathrm{mg}, t_{\mathrm{R}} 29-30 \mathrm{~min}, 0.022 \%\right.$ dry $\left.w t\right)$.

\subsection{Denhaminol O (1)}

Colourless gum; $[\alpha]_{D}^{24}-40.2$ (c 0.520, MeOH); ECD $\lambda_{\text {ext }}(\mathrm{MeOH}) 214(-4.63), 231$ (0.19), $267(-3.55) \mathrm{nm}$; UV (MeOH) $\lambda_{\max }(\log \varepsilon) 281$ (4.36) nm; IR (UATR) $v_{\max } 3409,2979,1747,1705$, 1634, 1386, 1256, 1197, 1161, 1077, 973, $768 \mathrm{~cm}^{-1} ;{ }^{1} \mathrm{H}-\mathrm{NMR}\left(\mathrm{CDCl}_{3}, 800 \mathrm{MHz}\right)$ see Table $2 ;{ }^{13} \mathrm{C}-\mathrm{NMR}$ $\left(\mathrm{CDCl}_{3}, 200 \mathrm{MHz}\right)$ see Table 3; (+)-LRESIMS $m / z 615[\mathrm{M}+\mathrm{H}]^{+} ;(+)$-HRESIMS $m / z 637.2595[\mathrm{M}+\mathrm{Na}]^{+}$ (calcd for $\mathrm{C}_{33} \mathrm{H}_{42} \mathrm{O}_{11} \mathrm{Na}$, 637.2619).

\subsection{Denhaminol P (2)}

Colourless gum; $[\alpha]_{D}^{24}-36.0$ (c 0.075, MeOH); ECD $\lambda_{\text {ext }}(\mathrm{MeOH}) 217(-4.79), 268(-3.81) \mathrm{nm}$; UV (MeOH) $\lambda_{\max }(\log \varepsilon) 282(4.38) \mathrm{nm}$; IR (UATR) $v_{\max }$ 2952, 1739, 1705, 1373, 1197, 1162, 1076, 975, $769 \mathrm{~cm}^{-1} ;{ }^{1} \mathrm{H}-\mathrm{NMR}\left(\mathrm{CDCl}_{3}, 800 \mathrm{MHz}\right)$ see Table $2 ;{ }^{13} \mathrm{C}-\mathrm{NMR}\left(\mathrm{CDCl}_{3}, 200 \mathrm{MHz}\right)$ see Table 3; (+)-LRESIMS $m / z 657[\mathrm{M}+\mathrm{H}]^{+} ;(+)$-HRESIMS $m / z 679.2693[\mathrm{M}+\mathrm{Na}]^{+}\left(\right.$calcd for $\mathrm{C}_{35} \mathrm{H}_{44} \mathrm{O}_{12} \mathrm{Na}$, 679.2725).

\subsection{Denhaminol Q (3)}

Colourless gum; $[\alpha]_{D}^{24}-33.3$ (c $\left.0.510, \mathrm{MeOH}\right) ; \mathrm{ECD} \lambda_{\mathrm{ext}}(\mathrm{MeOH}) 216(-4.60), 253(-2.01)$, $301(0.29) \mathrm{nm}$; UV (MeOH) $\lambda_{\max }(\log \varepsilon) 630(4.441) \mathrm{nm}$; IR (UATR) $v_{\max }$ 3419, 2971, 1747, 1710, 1391, 1278, 1120, 1163, 1078, 974, $713 \mathrm{~cm}^{-1},{ }^{1} \mathrm{H}-\mathrm{NMR}\left(\mathrm{CDCl}_{3}, 800 \mathrm{MHz}\right)$ see Table $2 ;{ }^{13} \mathrm{C}-\mathrm{NMR}\left(\mathrm{CDCl}_{3}\right.$, $200 \mathrm{MHz}$ ) see Table 3; (+)-LRESIMS $m / z 631[\mathrm{M}+\mathrm{H}]^{+}, 653[\mathrm{M}+\mathrm{Na}]^{+} ;(+)$-HRESIMS $m / z 653.2531$ $[\mathrm{M}+\mathrm{Na}]^{+}$(calcd for $\left.\mathrm{C}_{33} \mathrm{H}_{42} \mathrm{O}_{12} \mathrm{Na}, 653.2568\right)$. 


\subsection{Denhaminol R (4)}

Colourless gum; $[\alpha]_{D}^{24}-18.2$ (c 0.110, MeOH); ECD $\lambda_{\text {ext }}(\mathrm{MeOH}) 216(-5.37), 235(0.92)$, 279 (-1.31) nm; UV (MeOH) $\lambda_{\max }(\log \varepsilon) 224$ (4.42), 281 (4.39) nm; IR (UATR) $v_{\max }$ 3414, 2981, 1746, $1709,1635,1277,1199,1163,1077,973,712 \mathrm{~cm}^{-1} ;{ }^{1} \mathrm{H}-\mathrm{NMR}\left(\mathrm{CDCl}_{3}, 800 \mathrm{MHz}\right)$ see Table $2 ;{ }^{13} \mathrm{C}-\mathrm{NMR}$ $\left(\mathrm{CDCl}_{3}, 200 \mathrm{MHz}\right)$ see Table 3; (+)-LRESIMS m/z $653[\mathrm{M}+\mathrm{H}]^{+} ;(+)$-HRESIMS m/z $675.2400[\mathrm{M}+\mathrm{Na}]^{+}$ (calcd for $\mathrm{C}_{35} \mathrm{H}_{40} \mathrm{O}_{12} \mathrm{Na}, 675.2412$ ).

\section{Conclusions}

A UHPLC-MS method and dereplication process was developed for the rapid identification of new dihydro- $\beta$-agarofurans from Celastraceae plants. This study further exemplifies how UHPLC-MS data and database mining can be used to extract molecular features related to characteristic secondary metabolites of a plant family and thus expedite new discoveries in natural products research. This approach was successfully applied to 16 Australian Celastraceae plant extracts. Consequently, four previously undescribed dihydro- $\beta$-agarofurans (denhaminols $O-R, 1-4$ ) along with a known compound denhaminol G (5) were successfully isolated and characterised from one prioritised plant sample, namely the fruits of $D$. celastroides. Other Celastraceae samples that were prioritised for large-scale extraction and isolation studies will be investigated in the future. The pure compounds reported in this paper will be added to the Davis Open-Access Compound Library which is housed at Compounds Australia, Griffith University [19,22-25] and will be tested in various bioassays in the future. It is worth mentioning and well-known that the chemical profile of a plant can vary due to different geographical locations and collection seasons; however, even though this research utilised only Queensland Celastraceae plants, the UHPLC-MS method developed here should be applicable to the chemical profiling of any plant sample. Furthermore, this UHPLC-MS methodology should be adaptable to the chemical investigation of any biota material, including not only plants but also microbes, marine invertebrates and fungi.

Supplementary Materials: The following materials are available online at http:/ / www.mdpi.com/1420-3049/ 24/5/859/s1: 1D/2D NMR spectra of compounds 1-4, ECD spectra of 1-5 and diagnostic 2D correlations for compounds 2-4; Australian Celastraceae plant collection date, location and voucher specimen codes.

Author Contributions: R.A.D. and M.W. conceived, designed and conceptualised the study. M.W. collected the data and literature for the manuscript and performed the experiments. P.I.F. and G.P.G. supplied all the plant material to NatureBank and provided the taxonomic identification for all the plants. R.A.D. and A.H. supervised the study. M.W., R.A.D. and A.H. wrote the manuscript and all authors reviewed the manuscript. All authors have read and approved the final version of the manuscript.

Funding: This research was supported by funding from the Australian Research Council (ARC) for NMR and MS equipment (Grant Nos. LE0668477, LE140100119 and LE0237908) and a New Concept Grant (NCG 2416) through the Prostate Cancer Foundation of Australia's Research Program (R.A.D.).

Acknowledgments: R.A.D., M.W. and A.H. acknowledge the NatureBank biota repository (www.griffith.edu.au/ gridd) from which all the plant material was accessed. M.W. acknowledges Griffith University for the provision of the Ph.D. scholarships (Griffith University Postgraduate Research Scholarship and Griffith University International Postgraduate Research Scholarship).

Conflicts of Interest: The authors declare no conflict of interest.

\section{References}

1. Spivey, A.C.; Weston, M.; Woodhead, S. Celastraceae sesquiterpenoids: Biological activity and synthesis. Chem. Soc. Rev. 2002, 31, 43-59. [CrossRef] [PubMed]

2. Callies, O.; Sánchez-Cañete, M.P.; Gamarro, F.; Jiménez, I.A.; Castanys, S.; Bazzocchi, I.L. Restoration of chemosensitivity in P-glycoprotein-dependent multidrug-resistant cells by dihydro- $\beta$-agarofuran sesquiterpenes from Celastrus vulcanicola. J. Nat. Prod. 2015, 78, 736-745. [CrossRef] [PubMed]

3. Perestelo, N.R.; Jiménez, I.A.; Tokuda, H.; Vázquez, J.T.; Ichiishi, E.; Bazzocchi, I.L. Absolute configuration of dihydro- $\beta$-agarofuran sesquiterpenes from Maytenus jelskii and their potential antitumor-promoting effects. J. Nat. Prod. 2016, 79, 2324-2331. [CrossRef] [PubMed] 
4. Alarcón, J.; Cespedes, C.L.; Muñoz, E.; Balbontin, C.; Valdes, F.; Gutierrez, M.; Astudillo, L.; Seigler, D.S. Dihydroagarofuranoid sesquiterpenes as acetylcholinesterase inhibitors from celastraceae plants: Maytenus disticha and Euonymus japonicus. J. Agric. Food Chem. 2015, 63, 10250-10256. [CrossRef] [PubMed]

5. Wang, D.-M.; Zhang, C.-C.; Zhang, Q.; Shafiq, N.; Pescitelli, G.; Li, D.-W.; Gao, J.-M. Wightianines A-E, Dihydro- $\beta$-agarofuran sesquiterpenes from Parnassia wightiana, and their antifungal and insecticidal activities. J. Agric. Food Chem. 2014, 62, 6669-6676. [CrossRef] [PubMed]

6. Sasikumar, P.; Sharathna, P.; Prabha, B.; Varughese, S.; Anil Kumar, N.; Sivan, V.V.; Sherin, D.R.; Suresh, E.; Manojkumar, T.K.; Radhakrishnan, K.V. Dihydro- $\beta$-agarofuran sesquiterpenoids from the seeds of Celastrus paniculatus Willd. and their $\alpha$-glucosidase inhibitory activity. Phytochem. Lett. 2018, 26, 1-8.

7. Mba'ning, B.M.; Lenta, B.N.; Noungoué, D.T.; Antheaume, C.; Fongang, Y.F.; Ngouela, S.A.; Boyom, F.F.; Rosenthal, P.J.; Tsamo, E.; Sewald, N.; et al. Antiplasmodial sesquiterpenes from the seeds of Salacia longipes var. camerunensis. Phytochemistry 2013, 96, 347-352. [CrossRef] [PubMed]

8. Wibowo, M.; Wang, Q.; Holst, J.; White, J.M.; Hofmann, A.; Davis, R.A. Celastrofurans A-G: Dihydro- $\beta$-agarofurans from the Australian rainforest vine Celastrus subspicata and their inhibitory effect on leucine transport in prostate cancer cells. J. Nat. Prod. 2017, 80, 1918-1925. [CrossRef] [PubMed]

9. Wibowo, M.; Wang, Q.; Holst, J.; White Jonathan, M.; Hofmann, A.; Davis Rohan, A. Dihydro- $\beta$-agarofurans from the Australian endemic rainforest plant Denhamia pittosporoides inhibit leucine transport in prostate cancer cells. Asian J. Org. Chem. 2016, 5, 1461-1466. [CrossRef]

10. Wibowo, M.; Wang, Q.; Holst, J.; White, J.M.; Hofmann, A.; Davis, R.A. Dihydro- $\beta$-agarofurans from the roots of the Australian endemic rainforest tree Maytenus bilocularis act as leucine transport inhibitors. Phytochemistry 2018, 148, 71-77. [CrossRef] [PubMed]

11. Yang, J.; Liang, Q.; Wang, M.; Jeffries, C.; Smithson, D.; Tu, Y.; Boulos, N.; Jacob, M.R.; Shelat, A.A.; $\mathrm{Wu}, \mathrm{Y}$;; et al. UPLC-MS-ELSD-PDA as a powerful dereplication tool to facilitate compound identification from small-molecule natural product libraries. J. Nat. Prod. 2014, 77, 902-909. [CrossRef] [PubMed]

12. Eugster, P.J.; Wolfender, J.L. Chapter 13 UHPLC in Natural Products Analysis. In UHPLC in Life Sciences; The Royal Society of Chemistry: London, UK, 2012; pp. 354-386.

13. Qiu, X.; Zhang, J.; Huang, Z.; Zhu, D.; Xu, W. Profiling of phenolic constituents in Polygonum multiflorum Thunb. by combination of ultra-high-pressure liquid chromatography with linear ion trap-orbitrap mass spectrometry. J. Chromatogr. A 2013, 1292, 121-131. [CrossRef] [PubMed]

14. Bertrand, S.; Schumpp, O.; Bohni, N.; Bujard, A.; Azzollini, A.; Monod, M.; Gindro, K.; Wolfender, J.-L. Detection of metabolite induction in fungal co-cultures on solid media by high-throughput differential ultra-high pressure liquid chromatography-time-of-flight mass spectrometry fingerprinting. J. Chromatogr. A 2013, 1292, 219-228. [CrossRef] [PubMed]

15. Gaudencio, S.P.; Pereira, F. Dereplication: Racing to speed up the natural products discovery process. Nat. Prod. Rep. 2015, 32, 779-810. [CrossRef] [PubMed]

16. Eugster, P.J.; Boccard, J.; Debrus, B.; Bréant, L.; Wolfender, J.-L.; Martel, S.; Carrupt, P.-A. Retention time prediction for dereplication of natural products $(\mathrm{CxHyOz})$ in LC-MS metabolite profiling. Phytochemistry 2014, 108, 196-207. [CrossRef] [PubMed]

17. SciFinder Scholar. Available online: http:/ / scifinder.cas.org/ (accessed on 15 June 2018).

18. Dictionary of Natural Products. Available online: http:/ / dnp.chemnetbase.com (accessed on 15 June 2018).

19. NatureBank, Griffith Institute for Drug Discovery. Available online: http://griffith.edu.au/gridd (accessed on 15 June 2018).

20. Levrier, C.; Sadowski, M.C.; Nelson, C.C.; Healy, P.C.; Davis, R.A. Denhaminols A-H, dihydro- $\beta$-agarofurans from the endemic Australian rainforest plant Denhamia celastroides. J. Nat. Prod. 2015, 78, 111-119. [CrossRef] [PubMed]

21. Weeratunga, S.; Hu, N.-J.; Simon, A.; Hofmann, A. SDAR: A practical tool for graphical analysis of two-dimensional data. BMC Bioinform. 2012, 13, 201. [CrossRef] [PubMed]

22. Dilrukshi Herath, H.M.P.; Preston, S.; Hofmann, A.; Davis, R.A.; Koehler, A.V.; Chang, B.C.H.; Jabbar, A.; Gasser, R.B. Screening of a small, well-curated natural product-based library identifies two rotenoids with potent nematocidal activity against Haemonchus contortus. Vet. Parasitol. 2017, 244, 172-175. [CrossRef] [PubMed] 
23. Zulfiqar, B.; Jones, A.J.; Sykes, M.L.; Shelper, T.B.; Davis, R.A.; Avery, V.M. Screening a natural product-based library against kinetoplastid parasites. Molecules 2017, 22, 1715. [CrossRef] [PubMed]

24. Egbewande, F.A.; Sadowski, M.C.; Levrier, C.; Tousignant, K.D.; White, J.M.; Coster, M.J.; Nelson, C.C.; Davis, R.A. Identification of gibberellic acid derivatives that deregulate cholesterol metabolism in prostate cancer cells. J. Nat. Prod. 2018, 81, 838-845. [CrossRef] [PubMed]

25. Egbewande, F.A.; Nilsson, N.; White, J.M.; Coster, M.J.; Davis, R.A. The design, synthesis, and anti-inflammatory evaluation of a drug-like library based on the natural product valerenic acid. Bioorg. Med. Chem. Lett. 2017, 27, 3185-3189. [CrossRef] [PubMed]

Sample Availability: Samples of the compounds are not available from the authors.

(C) 2019 by the authors. Licensee MDPI, Basel, Switzerland. This article is an open access article distributed under the terms and conditions of the Creative Commons Attribution (CC BY) license (http:// creativecommons.org/licenses/by/4.0/). 